\title{
Література:
}

1. McIntosh, A., Devereux, C. Lucy Maud Montgomery. The Canadian encyclopedia. URL: https://thecanadianencyclopedia.ca/en/article/ montgomery-lucy-maud

2. Крістева Ю. Жінка ніколи не така. Ю. Крістева. Полілог. К. : Юніверс, 2004. 480 с. С. $454-460$.

3. Кретов П. В., Кретова О. І. Гендер, письмо та ідентичність: від фемінітиву до метафізики статі. Вісник Черкаського університету: Серія «Філософія». Наук. журнал. №2. Черкаси, 2017. С. 3 - 11.

DOI https://doi.org/10.30525/978-9934-26-180-0-9

\section{РЕПРЕЗЕНТАЦІЯ АНАЛІТИЧНОЇ МОДЕЛІ ХУДОЖНЬОГО ТЕКСТУ В РОМАНІ ДЖ. С. ФОЕРА «СТРАШЕННО ГОЛОСНО ТА НЕЙМОВІРНО БЛИЗЬКО»}

\author{
Кохан Р. А. \\ кандидат філологічних наук, \\ дочент кафедри іноземних мов для природничих факультетів \\ Львівський національний університет імені Івана Франка \\ м. Львів, Украӥна
}

Процес аналізу накладання та втілення художніх смислів літературного твору становить складну матрицю розпізнавання різновимірних кодів: авторська інтенція та читацькі очікування й настанови, рецептивна свідомість автора і читача, їхні емоційні максими під час співтворення художнього часопростору. Особливої якості ці передумови набувають 3 огляду на тенденції сучасного літературного процесу - «визначена невизначеність» тих характеристик, в ореолі яких дослідники конфронтують 3 проблемними питаннями щодо художнього твору, маркує гуманітарне сьогодення переважаючою стохастичністю. Постмодернізм, постпостмодернізм, метамодернізм - численні номінації та потреба влучних визначень, а, відтак, і точок опори, що відцентровуватимуть наукові прагнення, заводять дослідницький дискурс у філософсько-культурологічні лабіринти, що стирають усталені категоріальні межі і, відповідно, спричиняють множинні та щораз нові взаємодії та впливи.

Уведення структуралістських понять - «модель», «моделювання» - у дискурс феноменологічної, герменевтичної та рецептивної методології 38 
дослідження літературного твору пропонує широку перспективу поглиблених поетологічних та поетикальних студій. Про слушність методологічних взаємопоєднань свідчать численні дослідження сучасних науковців. 3. Мітосек відносить до ключових характеристик літератури «неоднозначність, плинність й відкритість» [4, с. 8], 3 огляду на які література $є$ предметом, «який залишаючись у сфері суспільної практики, безнастанно змінює свої межі, трансформує свої властивості і функції» $[4$, c. 8]. Принципова змінюваність як домінантна якість естетичної природи літератури безпосередньо взаємопов'язана 3 іiі феноменологічними домінантами: «Творча уява, мудрість, розум і смак повинні 3'єднатися, щоби народити досконалий твір мистецтва» [2, с. 21], відтак, «простір літератури як історії писання/читання є ілюстрацією мінливої, динамічної сцени, де неперервно народжувався і здійснювався інтелектуальний, естетичний, етичний вибір окремої особи, груп індивідів, а то й усієї спільноти» [3, с. 20]. Принципово важливим, на наш погляд, $\epsilon$ використання поняття моделі з метою своєрідного термінологічного упорядкування - однозначного структурування літературного твору не існує, оскільки множинні смисли, накладені на художню площину, в процесі рецепції розбудовують невичерпну ієрархію значень та розумінь. Відповідно, завдяки логічному та структурованому синтезові поетикальних ознак у межах певної смислової моделі аналітичні зусилля в обраному напрямі дослідження твору можуть стати послідовними, завершеними та цілісними.

Для осмислення специфіки моделювання художнього світу літературного твору застановимося на категорії радості та спроектуємо можливу модель розбудови поетикальної парадигми на матеріалі роману американського письменника Джонатана Сафрана Фоера «Страшенно голосно та неймовірно близько». Водночас уважаємо, що доцільно зблизити рівні «художньої моделі» та «аналітичної моделі». Відтак, художньо-аналітична модель репрезентує унікальні параметри «накладання» літературного твору на дійсність та «виформатування» неповторного художнього світу на основі його внутрішніх суперечностей 3 подальшим процесом смислового співтворення у процесі рецепції як розкодування смислів.

Роман Дж. С. Фоера постає особливо цікавим об'єктом літературознавчого аналізу з огляду на домінантні риси сюжетотворення та проблемні точки закорінення авторської моделі, запропоновані сучасним американським письменником.

Насамперед зазначимо, що композиційним та смислотвірним центром художньої моделі роману є поняття «самого себе», що в ході розгортання 
сюжету та в процесі реалізації авторського та читацького «горизонтів очікувань» стає полем змагань - розуміння, очікувань та досягнень, тексту та зображення, почутих та непочутих звуків тощо. Характеристики такого роду є однозначною властивістю метамодерністичного тексту, який у процесі своєї парадоксально-змагальної реалізації набуває сенсу і, відтак, стає твором.

Конфігуративна площина романного наративу Фоера розбудовується довкола постаті Оскара Шелла - головного героя, однак попри це жоден iз персонажів не стає композиційно другорядним чи рецептивно менш значимим. Завдяки суперечливо і водночас цілісно розбудованій персоносфері рецептивна модель роману про «післятерактне» сьогодні однієї сім’ї на тлі тисяч однаково зруйнованих інших постає простором для когнітивно-рольової гри «автор-герой-читач», де розмежування ролей нівелювається на користь закодованих у художній площині твору смислів. Пошуки Оскара Шелла, чий батько Томас загинув в одній із веж-близнючок торгового центру під час теракту в Нью-Йорку, в кульмінаційний момент «рецептивного наближення» стають пошуками читача, а сформульоване протагоністом питання - «Чому я не там, де ти?» $[5$, c. $25,120,289]$ - що, як в ході сюжету дізнається читач, є багаторічною доленосною головоломкою для декількох поколінь цієї сім’'і, у момент породження твором «зразкового читача» (за У. Еко) видається питанням, на яке повинен відповісти, власне, читач.

Погоджуємося, що «простір письмового тексту вступає у нескінченний комунікативний процес, щоб оживити дух мертвих літер і дати їм шанс промовляти через проекцію внутрішнього світу тексту на зовнішній світ комунікативного середовища. Світ тексту доволі легко й навіть природно входить у світ дійсності читача, оскільки, згідно з чудовим порівнянням Р. Барта, письмо - це особливий «голос життя»» [3, с. 174]. Запропонована Р. Бартом метафора чітко репрезентує основні кроки реалізації художньої моделі: «можна сказати, що будь-який класичний текст (текст-читання) імпліцитно втілює в собі все мистецтво Повної Літератури - літератури наповненої, наче комод, де в повному порядку [...] акуратно розкладені всеможливі смисли (в такому тексті ніщо і ніколи не губиться, адже смисл дошукується до всього)» [1, с. 184]. Закодування автором смислів, що $€$ суб'єктивним дзеркалом дійсності, а потім рецептивне розкодування діалектичних констант - творення художньої літератури інтенсивно триває також і впродовж ії читацької реалізації.

Модель трагічного світосприймання розгортається у літературному творі, маркованому настроями метамодернізму, таким чином, що цілковитий катарсис збігається із моментом остаточного осмислення 
трагедії. Ймовірний зворотний відлік до потрібного людській свідомості щасливого розв'язання історії чи зумовлена психікою сучасного «Я» потреба «досягнути дна» і таким чином знайти опору/трамплін особливість аналітичної структури сучасного роману полягає, на наш погляд, у тому, що він становить своєрідний «початок координат», «нуль», який дає невичерпні можливості до трактувань, серед яких, однак, лише одне $\epsilon$ істинним. Відтак, читач метамодерністичного твору, перегортаючи першу сторінку, «вплутується» в художню авантюру, стає на такий-собі шлях пошуку філософського каменя, де безліч «всеможливих смислів» творять аксіологічно-гносеологічну парадигму.

\title{
Література:
}

1. Барт P. S/Z. Москва : Эдиториал УРCC, 2001. 232 с.

2. Гиршман М. Литературное произведение: теория художественной целостности. Москва : Языки славянской культуры, 2002. 560 с.

3. Зубрицька M. Homo legens : читання як соціокультурний феномен. Львів : Літопис, 2004. 352 с.

4. Мітосек 3. Теорії літературних досліджень / пер. 3 пол. В. Гуменюк ; наук. ред. В. Іванюк. Сімферополь : Таврія, 2005. 407 с.

5. Фоер Дж. С. Страшенно голосно і неймовірно близько / пер. з англ. О. Постранської. Харків : Клуб сімейного дозвілля, 2015. 384 с.

DOI https://doi.org/10.30525/978-9934-26-180-0-10

\section{СЕМАНТИЧНА ТА ФУНКЦІОНАЛЬНА ХАРАКТЕРИСТИКА СТИЛІСТИЧНО-МАРКОВАНОЇ ЛЕКСИКИ ІСТОРИЧНОЇ ПРОЗИ БОГДАНА ЛЕПКОГО}

\author{
Михайленко В. В.
}

кандидат філологічних наук,

старший викладач кафедри зарубіжної літератури та основ риторики

Комунальний заклад вищої освіти

«Вінницький гуманітарно-педагогічний коледж»

м. Вінниця, Украӥна

Вживання діалектизмів зі стилістичною метою пов'язане з естетичнохудожньою функцією мови. Так, у сучасних художніх творах основна їхня функція полягає в тому, «...що письменник, вживаючи діалектні елементи 